\title{
Effect of Quercetin on Infectious Pancreatic Necrosis Virus: in Vitro Replication Study
}

\author{
Şermin Yıldırım ${ }^{1, *} \mathbb{0}$, Semra Gümüşova ${ }^{1}$ \\ ${ }^{1}$ Ondokuz Mayıs University, Veterinary Faculty, Virology Department
}

\section{Article History}

Received 09 June 2020

Accepted 09 September 2020

First Online 17 September 2020

\section{Corresponding Author}

Tel.: +905397260512

E-mail: sermin.onkol@gmail.com

\author{
Keywords \\ IPNV \\ Quercetin \\ Cytotoxicity \\ Antiviral Activity
}

\begin{abstract}
Infectious Pancreatic Necrosis Virus (IPNV) is a viral agent that causes significant losses in salmonid fish in the rainbow trout and salmon farming sectors. The present study aimed to examine of quercetin effects on (IPNV) replication in Rainbow trout gonad (RTG-2) cell cultures. Half-maximal (50\%) cytostatic concentration (CC 50) of quercetin were detected in the RTG-2 cell culture by cytotoxicity test with Cell Counting Kit-8 (CCK-8, Sigma-Aldrich) ( $n=3$ ). Titration, cytopathogenic effect reduction, and qRT-PCR tests were used to determine the effect of quercetin on IPNV replication in RTG-2 cell culture. At the end of the cytotoxicity test, the non-toxic dose of quercetin was determined. Besides that, $50 \mu \mathrm{mol} / \mathrm{L}$ quercetin decreased the titer of IPNV in RTG-2 cells from $10^{-7}$ to $10^{-5}$, at the same time, the same dose of quercetin reduced the viral load to $40 \%$. We concluded that quercetin is a potent antioxidant agent for IPNV infections and it can be an option in the treatment of the IPN disease.
\end{abstract}

\section{Introduction}

Aquaculture is one of the fastest growing sectors in the world, due to the increasing demand for it in food production systems Lymbery (2000) and rainbow trout (Oncorhynchus mykiss) is one of the most produced fish species in aquaculture both in Turkey and the world (Anonymous, 2013).

IPNV is a viral agent that causes significant losses in salmonid fish in the rainbow trout and salmon farming sectors. The virus is a double-stranded RNA virus classified within the Aquabirnavirus genus of the Birnaviridae family (Anonymous, 2009). IPNV prevalence was determined many times both in Turkey and the world (Suzuki \& Nojima, 1999; Candan, 2002; Nishizawa et al. 2008; Ogut \& Altuntas, 2011). So, it is obvious that effective antiviral agents are necessary for successful treatment. On this matter, many investigations of antiviral activities had been done on
Infectious Hematopoietic Necrosis Virus (IHNV) and Viral Hemorrhagic Septicemia Virus (VHSV) using fustin, fisetin, butine and sulfuretin flavonoids that were extracted from Rhus verniciflua (Kang et al. 2012).

Oxidative stress is the increase in amount of free radicals that called reactive oxygen species (ROS) produced by physiological events during normal metabolism in all cells and rendered harmless by antioxidants (Halliwell, 1994). Many studies have shown that eukaryotic cells are the source of these free radicals as they use oxygen to generate energy from normal metabolic activities, moreover, viruses may cause cell damage due to the oxidative stress that occurs during replication (Muller, 1992; Najafi et al. 2014; Gullberg et al. 2015) and affect pathogenicity (Stehbens \& Nojima, 2004; Dikici et al. 2005; Ivanov et al. 2013). The damage of reactive oxygen products is inevitable for all fishes that breathe oxygen. Oxidative stress and antioxidant defense mechanisms in fish have been investigated in 
terms of damages caused by toxic substances such as heavy metals (Bayir et al. 2011). Also, a study reported that betanodaviruses can cause cell damage caused by oxidative stress (Chang et al. 2011).

Antioxidants are substances that can control free radicals and minimize their effects against the damage of reactive oxygen species. Also it has been determined that flavonoids have effective antioxidant activities in this regard by preventing the formation of ROS or by removing ROS directly (Frankel et al. 1993). Quercetin is also an important aglycone flavonoid that known to be a powerful natural antioxidant both in vitro and in vivo (Nabavi, Nabavi, Eslami \& Moghaddam, 2012). Quercetin has been reported to be effective for human health as antioxidant, anti-cancer, anti-diabetic, antiinfective, anti-inflammatory and blood pressure regulator (Kelly, 2011; Larson et al. 2012). In recent years, the antiviral activity of quercetin on many viruses such as Influenza virus, Ebola virus, Chikungunya virus, Epstein-Barr virus, Hepatitis C virus, and Mayaro virus has also been investigated (Lani et al. 2015; Lee et al. 2015; Abdal et al. 2015; Qiu et al. 2016). In this study, the effect of quercetin on IPNV replication in the fish cell cultures, and the non-toxic dose of quercetin on Rainbow Trout Gonad-2 (RTG-2) cell were examined for the first time.

\section{Materials and Method}

\section{RTG-2 Cell Culture Preparation}

In this study, RTG-2 continuous cell culture and IPNV SDF4 strain, obtained from the stocks of Virology Department, Faculty of Veterinary Medicine, Ondokuz Mayis University, were used for the production, titration and cytotoxicity tests of quercetin. RTG-2 cells that used for virus inoculation and cell suspension were grown in Leibovitz's L-15 Medium (1X) (Gibco Life Technologies Cat. No: $11415-056$, UK) in $25 \mathrm{~cm}^{2}$ cell culture flasks (Corning, NY 14831, USA) with the addition of $10 \%$ fetal calf serum (Sigma- Aldrich Cat. No: F9665, USA) with 1\% penicillin-streptomycin antibiotic solution (Biological Industries, Cat, 03-33-1B, Israel). Then, the cells were removed daily from the $22^{\circ} \mathrm{C}$ oven to be monitored on a tissue culture microscope (Olympus, CKX41, Japan). Then the suspension of RTG- 2 cells that contains $1 \times 10^{6}$ cells per milliliter was prepared and used in the cytotoxicity test.

\section{IPNV Inoculation}

When the cells covered approximately $80 \%$ of the flask surface as a monolayer during the virus cultivation stage, IPNV inoculation was performed by absorbing method after pouring the cell production medium. At the end of the incubation period, L-15 medium with bovine serum was added and then was flask incubated at $15^{\circ} \mathrm{C}$ oven. Cells than contains the virus inoculum was checked daily for tissue cytopathic effect (CPE) by tissue culture microscope. Approximately 48-72 hours later, CPE formation was monitored, then cells that containing the virus were frozen at $-80^{\circ} \mathrm{C}$ and thawed three times, after that centrifugation at $+4^{\circ} \mathrm{C}$ and $3000 \mathrm{rpm}$ were done, and the resulting virus supernatants were placed into vials and stored at $-80^{\circ} \mathrm{C}$ deep freezing until used.

\section{Calculation of Half-Maximal (50\%) Cytostatic Concentration (CC 50 ) of Quercetin (Cytotoxicity Tests)}

Quercetin, whose effect on IPNV replication, was obtained from Sigma-Aldrich (Cat. No: 849061-97-8, USA). The half-maximal (50\%) cytostatic concentration (CC 50 ) of quercetin on RTG-2 cells was determined by (WST-8) viability test using Cell Counting Kit-8 (CCK-8, Sigma-Aldrich, Cat. No: 96992, USA). The test was performed on a 96-well plate (TPP zellkultur test plate 96F, Cat. No:92096, Switzerland) according to the method reported by the manufacturer. Five different concentrations of quercetin $(10,20,50$ and $100 \mu \mathrm{mol} / \mathrm{L})$ were used to determine the half-maximal (50\%) cytostatic concentration (CC 50) of quercetin. The plates were read at the end of the test in a microplate reader (Tecan Infinite F50) with an optical density (OD) of 450 nanometers $(\mathrm{nm})$ and the OD of each well was recorded on the microplate reader. The test was repeated 3 times and CC 50 of quercetin was calculated according to the formula "[(OD test-OD blank) / (OD control-OD blank)] $\times$ $100^{\prime \prime}$.

\section{Titration Test}

Microtitration test was performed to calculate the cell infective (TCID50) of IPNV with and without quercetin at half-maximal cytostatic concentration (CC 50 ). For this purpose, a serial dilution of IPNV according to $\log 10$ was made and $100 \mu$ l was placed in 4 wells of each microtitre tablet for each dilution. The same procedure was repeated in IPNV treated with quercetin at non-toxic concentrations $(10,20$ and $50 \mu \mathrm{mol} / \mathrm{L})$. Then, $50 \mu \mathrm{l}$ of the cell suspension was added to the dilutions with 300,000 live cells per $\mathrm{mL}$. Microtitre plates were monitored daily under the microscope for CPE formation and when CPE was formed in all four eyes of the virus control, test results were evaluated and titers were calculated according to Spearman-Kaerber method. (Frey \& Liess, 1971).

\section{Cytopathogenic Effect (CPE) Reduction Test}

The antiviral activity of IPNV in IPNV-infected cells with and without quercetin was performed by the method reported by Kujumgiev et al. (1999) using the "Cytopathogenic Effect (CPE) Reduction Test". Test results were evaluated as score $0,0 \% \mathrm{CPE}$; score 1, 025\% CPE; score 2, 35-50\% CPE; score 3, 50-75\% CPE; and score $4,75-100 \%$ CPE. 


\section{Calculation of Viral Load by Quantitative Real-Time PCR (qRT-PCR)}

Viral RNA obtained from IPNV supernatants that produced in RTG-2 cells which include different doses of quercetin at 10, 20 and $50 \mu \mathrm{mol} / \mathrm{L}$ that determined as non-toxic dose in cytotoxicity test was extracted with GeneJET RNA Purification Kit (Thermo, K0732) according to the manufacturer's instructions. For qRT-PCR, the number of viral particles was determined on the Biorad CFX Connect qRT-PCR using the iTaqTM Universal Probes One-Step Kit (Biorad, Cat. No: 172-5141) and IPNV primers and probes (Table 1). At the end of the test, the results were evaluated in Bio-Rad CFX Manager 3.1.

The mean value of the data obtained from three replicated cytotoxicity experiments was calculated. The differences in viral load between the three replicates, controls and the different doses of quercetin were expressed as \%.

\section{Results}

\section{Production of IPNV in RTG-2 Cell Culture}

RTG-2 cells used in virus generation, titration, cytotoxicity, and CPE reduction tests were photographed after tissue culture microscopy (Figure 1A). Then IPNV was inoculated on the RTG-2 cells prepared with the aim of producing the virus and the images were taken at 24,48 and 72 hours while checking by tissue culture microscope (Figure 1 / B-C-D).

\section{Cytotoxicity Test Results of Quercetin}

The CC 50 of quercetin on RTG-2 cells was determined using (WST-8) viability test Cell Counting Kit8 (CCK-8, Sigma-Aldrich). The mean of each concentration and control was plotted at different times for three trials. According to this; the Viability of cells treated with $50 \mu \mathrm{mol}$ quercetin calculated $52 \%$ after 24 hours and $50 \%$ at the end of 48 hours. Whereas, the viability of the cells treated with $100 \mu \mathrm{mol}$ quercetin was $47 \%$ after 24 hours and $49 \%$ after 48 hours (Figure 2 ).

Also, four flask cell cultures were grown $\left(25 \mathrm{~cm}^{2}\right)$ to calculate the effect of noncytotoxic concentrations (10, 20 and $50 \mu \mathrm{mol} / \mathrm{L}$ ) of quercetin on IPNV replication. When RTG-2 cells were occupied $80 \%$ of base flasks the cell growth medium was spilled and non-toxic doses (10, 20 and $50 \mu \mathrm{mol} / \mathrm{L}$ ) of quercetin were added at three flasks. To prepare the virus control, L15 medium was added in one flask and all of the four flasks were incubated for 2 hours at $22^{\circ} \mathrm{C}$. At the end of 2 hours, all contents were spilled and IPNV was inoculated in the four flasks then virus growth medium was added into all flasks. After that, the CPE formations were followed and photographed for 1 week (Figure 3).

\section{Microtitration Test Results}

At the end of the microtitration test, IPNV titers were calculated as $10^{-7} / 0,1 \mathrm{ml}$ for the untreated cells with quercetin, $10^{-6} / 0,1 \mathrm{ml}$ for the treated cells with $10 \mu \mathrm{mol} / \mathrm{L}$ quercetin and $10^{-5} / 0,1 \mathrm{ml}$ for cells that treated with both 20 and $50 \mu \mathrm{mo} / \mathrm{L}$ quercetin (Table 2).

Table 1 Primers and probe used for RT-PCR analysis of IPNV

\begin{tabular}{lc} 
Name & Primers and Probe \\
\hline VP3-F & F: 5'-TCTCCCGGGCAGTTCAAGT-3' \\
VP3-R & R: 5'-CGGTTTCACGATGGGTTGTT-3' \\
VP3-P & P:5'-FAM-CCAGAACCAGGTGACGAGTATGAGGACTACAT-3'-TAMRA \\
\hline
\end{tabular}

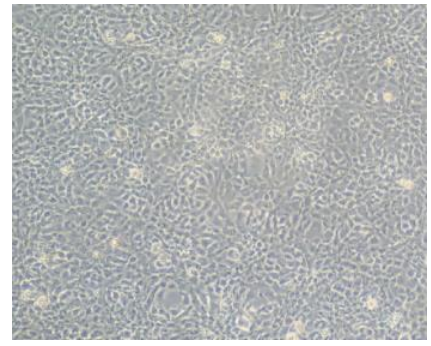

A

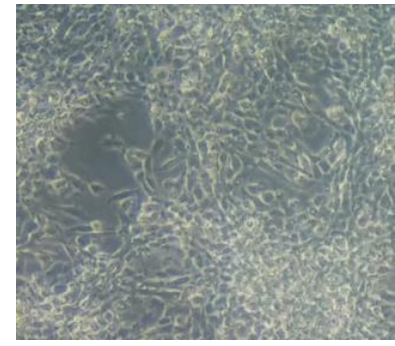

B

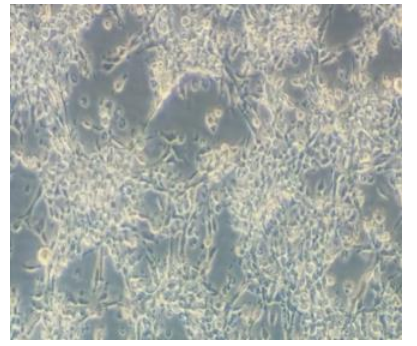

C

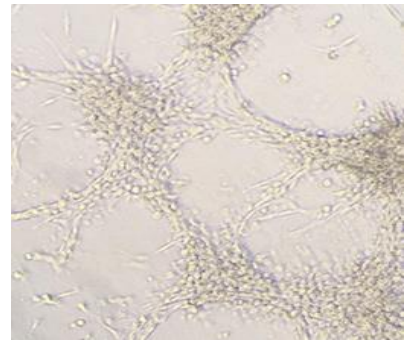

D

Figure 1. A: RTG-2 cell Culture (72h), B: 24th hour CPE image of IPNV C: 48th hour CPE image of IPNV, D: 72th hour CPE image of IPNV (x10). 


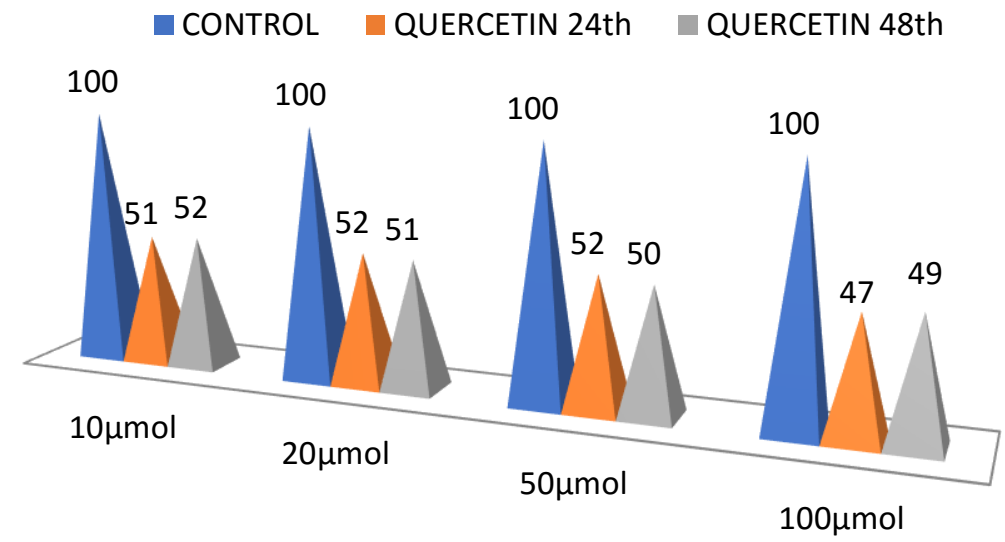

Figure 2. Cytotoxicity test cell survival rates of quercetin.

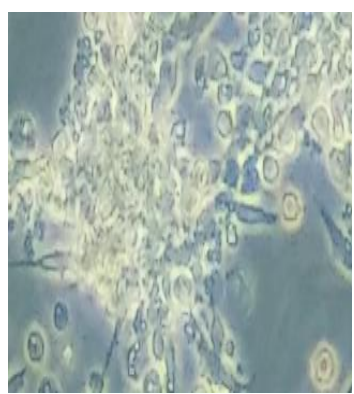

IPNV Control a

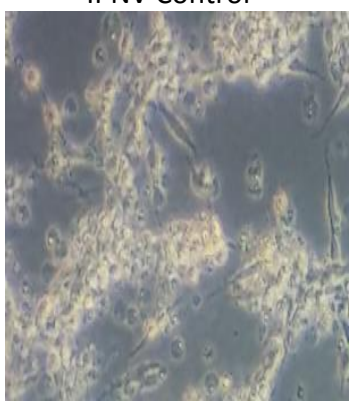

IPNV Control

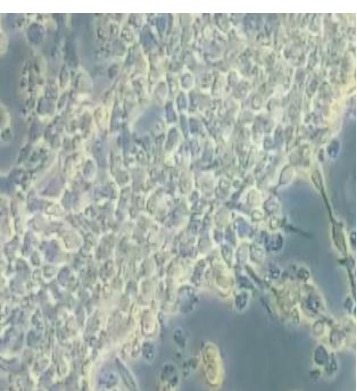

Flask 1

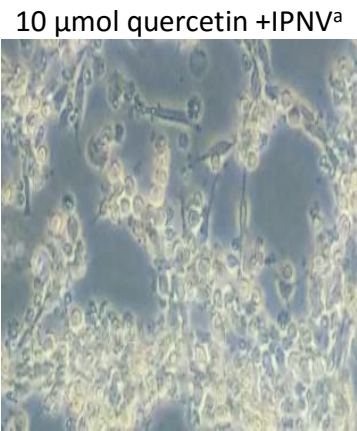

Flask 1

$10 \mu \mathrm{mol}$ quercetin +IPNVb

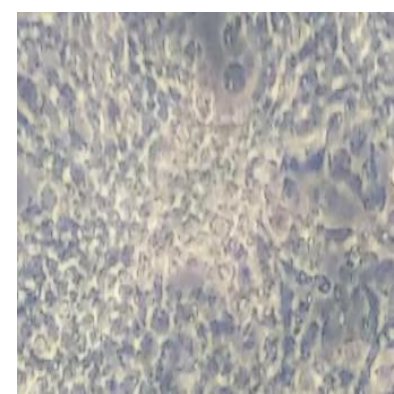

Flask 2

$20 \mu$ mol quercetin +IPNV

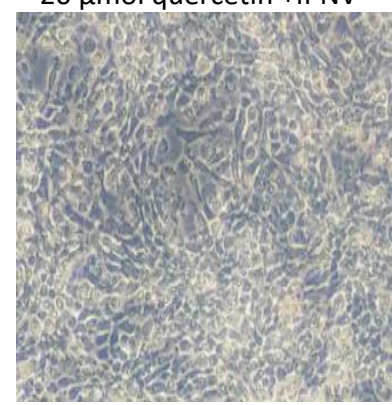

Flask 2

$20 \mu \mathrm{mol}$ quercetin +IPNV

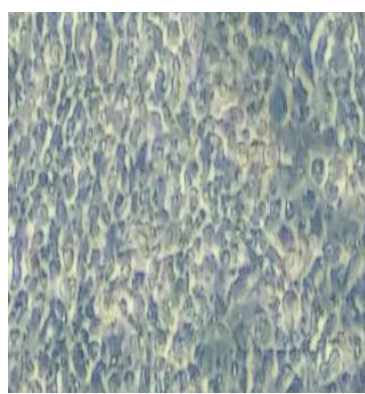

Flask 3

$50 \mu \mathrm{mol}$ quercetin +IPNVa

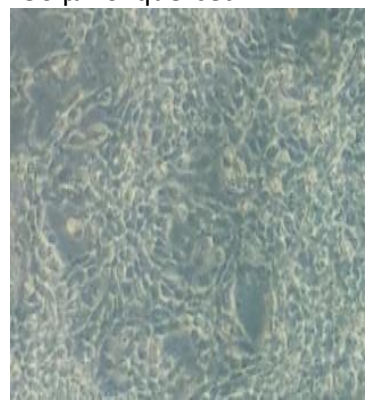

Flask 3

$50 \mu$ mol quercetin +IPNVb

Figure 3. CPE images of IPNV at $24 \mathrm{~h}\left({ }^{\mathrm{a}}\right)$ and $72 \mathrm{~h}\left(^{\mathrm{b}}\right)$ at different CC50 quercetin concentrations inoculated into RTG-2 cell culture (×10).

\section{Cytopathogenic Effect (CPE) Reduction Test Results}

The CC50 quercetin concentration $(50 / \mathrm{mol} / \mathrm{L})$ was detected by CKK- 8 assay in the RTG-2 cells and CPE of IPNV were scored by CPE reduction test under invert microscope to determine the effect of quercetine concentration on IPNV replication. At the end of the test, CPE formation was measured as score 1 (0-25\%) at flask 1 and virus control flask but no change as (score 0 ) was observed in flasks 2 and 3 after 24 hours. In addition, 35-50\% CPE formation was scored as 2 in flask 1 and IPNV virus control flask but $0-25 \%$ CPE formation was observed in the 2 nd and 3rd flask and they were scored as 1 at the end of 72 hours (Figure 3).

\section{Quantitative Real-Time PCR (qRT-PCR) Test Results}

The viral load of IPNV virus control and IPNV that was treated with different quercetin concentrations were calculated using the Biorad CFXManager 3.1 program. At the end of the qRT-PCR test, it was determined that viral loads were decreased $5 \%$ after $10 \mu \mathrm{mol} / \mathrm{L}$ quercetin application, $35 \%$ after $20 \mu \mathrm{mol} / \mathrm{L}$ quercetin application and $40 \%$ after $50 \mu \mathrm{mol} / \mathrm{L}$ quercetin application compared to IPNV virus control (Figure 4). 
Table 2 Infectious power of IPNV after non-quercetin and different doses of quercetin.

\begin{tabular}{ll}
\hline APPLICATIONS & DKID \\
50 VALUES
\end{tabular}

\begin{tabular}{|c|c|}
\hline IPNV & $10^{-7} / 0,1 \mathrm{ml}$ \\
\hline IPNV+10 $\mu \mathrm{mol} / \mathrm{L}$ Quercetin & $10^{-6} / 0,1 \mathrm{ml}$ \\
\hline IPNV+20 $\mu \mathrm{mol} / \mathrm{L}$ Quercetin & $10^{-5} / 0,1 \mathrm{ml}$ \\
\hline IPNV+50 $\mu \mathrm{mol} / \mathrm{L}$ Quercetin & $10^{-5} / 0,1 \mathrm{ml}$ \\
\hline
\end{tabular}

IPNV+Quercetin q-RT PCR

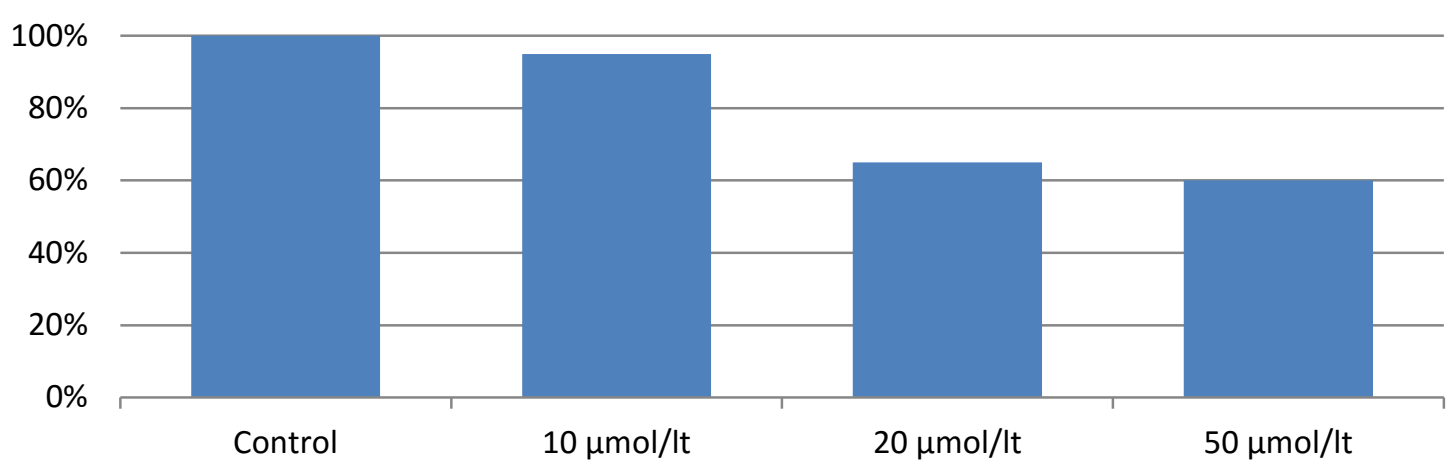

Figure 4. IPNV viral load after quercetin at different concentrations.

\section{Discussion}

Natural compounds are used as an important source for the discovery of new antiviral drugs because of their low side effects. Flavonoids have been known to have antiviral activity since the 1940s, and there are many studies on antiviral activity of various flavonoids (Özcelik et al. 2011; Ganesan et al. 2012; Yu et al. 2014; Cheng et al. 2015; Wu et al. 2016; Rojas et al. 2016). It has been reported that quercetin which is an important flavonoid and commonly found in foods in the form of aglycone or glycoside can be used as a protecting agent against oxidative stress Kumar, Sharma, Khanna \& Raj (2003) and reduces susceptibility to viral infection. (Davis, Murphy, McClellan, Carmichael \& Gangemi 2008). In this study, in vitro effect of quercetin in IPNV replication was investigated in term ofits antiviral effect in viral infections.

It had been reported by Cheng et al. (2015) that semi-maximal cytostatic concentration (CC50) of quercetin as $50 \mu \mathrm{mol} / \mathrm{L}$ in HepG2.2.15 (hepatocellular carcinoma) and $\mathrm{HuH}-7$ cells was significantly inhibited Hepatitis B Virus (HBV) replication in both cells at different time intervals $(2,4$, and 6th day). In another study, it had been reported that HepG2 2.2.15 cells can afford the semi-maximal cytostatic concentration (CC50) of quercetin to more than $100 \mu \mathrm{mol} / \mathrm{L}$. (Romero et al. 2005). In this study, the semi-maximal (50\%) cytostatic concentration of quercetin in RTG-2 cell at 48 hours was found to be $50 \mu \mathrm{mol} / \mathrm{L}\left(\mathrm{CC}_{50}\right)$ similar to the results of Cheng et al. (2015) who investigated the effect of quercetin on $\mathrm{HBV}$ replication, and detected that the inhibition of virus replication was started at $10 \mu \mathrm{mol} / \mathrm{L}$ quercetin concentrations, also HBV intracellular viral DNA levels in HepG2.2.15 and $\mathrm{HuH7}$ cells were calculated as $68.5 \%$ and $52.9 \%$, respectively. In addition, the level of HBV transcripts at $50 \mu \mathrm{mol} L$ quercetin concentration was analyzed and it was recorded that it inhibited viral transcription by (51.8\%) significantly (Cheng et al. 2015). Wu et al. (2016) had been stated that the inhibition effect of quercetin was $49.21 \%$ on influenza virus that was incubated with quercetin of 50 $\mu \mathrm{mol} / \mathrm{mL}$ concentration at $4^{\circ} \mathrm{C}$ for 30 minutes and then cultured at $37^{\circ} \mathrm{C}$ for 48 hours. Also, a study of Huh-7.5 cells that were infected with HCV JFH1 strain, revealed that viral load of the cells that were treated with $50 \mu \mathrm{M}$ quercetin decreased as $22.6 \%$ compared to the control cells (Rojas et al. 2016).

In this study, we compared the viral load of IPNV inoculated cells with viral load of cells that were treated with different concentrations of quercetin before IPNV inoculation. Our results for the percentage of viral loads reduction of IPNV were $5 \%$ at $10 \mu \mathrm{mol} / \mathrm{L}$ quercetin, 35\% at $20 \mu \mathrm{mol} / \mathrm{L}$ quercetin and $40 \%$ at $50 \mu \mathrm{mol} / \mathrm{L}$ quercetin. These results were found similar to other studies on different viruses that were detected antiviral 
activity of quercetin. Wu et al. (2016) had been reported that quercetin dose has reduced the HA mRNA transcription of influenza virus and 24 hours after the infection, viral NP protein synthesis in MDCK cells was inhibited. Also, aother study examined the effect of quercetin on HCV JFH1 strain and proved it caused decrease in infectious titer of virus (Rojas et al. 2016). In this research, the effect of quercetin on virus replication was determined by comparing quercetin-treated and non-treated IPNV titers. Accordingly, we revealed that the infectivity of non-quercetin-treated IPNV was calculated as $10^{-7} / 0,1 \mathrm{ml}$ but infectivity for the treated IPNV with 10, 20 and $50 \mu \mathrm{mol} / \mathrm{L}$ quercetin were decreased depends on the doses of quercetine as 10-6, 10-5 and 10-5, respectively. Our data was showed that the inhibitory effect of quercetin on IPNV was similar to $\mathrm{HCV}$ and influenza viruses studies.

As a result, this study was shown that quercetin has in vitro inhibitory effect on IPNV virus. and it may be considered as an option to treat IPN disease, but comprehensive animal experiments are needed for this matter.

\section{References}

Abdal, D.A., Choi, H.Y., Kim Y.B., \& Cho, S.G. (2015). Antiviral effect of methylated flavonol isorhamnetin against influenza. Plos One. 25, 10-3. https://doi.org/10.1371/journal.pone.0121610.

Anonymous, (2009). Birnaviridae International Committee on Taxonomy of Viruses. http://www.ncbi.nlm.nih.gov/ICTVdb/Ictv/fs_birna.htm

Anonymous, (2013). DiE, Su Ürünleri İstatistikleri. Başbakanlık, Ankara.

Bayır, A., Sirkecioglu, A.N., Bayir, M., Aras, N.M., Haliloglu, H.I., Kocaman, E.M., \& Aras, M.N. (2011). Metabolic responses to prolonged starvation, food restriction, and refeeding in the brown trout. Salmo trutta: Oxidative stress and antioxidant defenses. Comparative Biochemistry and Physiology Part B: Biochemistry and Molecular Biology, 159, 191-196. https://doi.org/10.1016/j.cbpb.2011.04.008.

Candan, A.(2002) First report on the diagnosis of infectious pancreatic necrosis (IPN) based on reverse transcription polymerase chain reaction (RT-PCR) in Turkey Bull Eur Ass. Fish Pathology, 221, 45-48. https://doi.org/10.33988/auvfd.537413.

Chang, Y., Yanga, J.H., Liua, J.H., Donga, E., Wanga, Y., Caoa, A., Liua, Y., \& Wanga, H. (2011). In vitro toxicity evaluation of graphene oxide on A549 cells. Toxicology Letters. 200(3), 201-210. https://doi.org/10.1016/j.toxlet.2010.11.016.

Cheng, Z., Sun, G., Guo, W., Huang, Y., Sun, W., Zhao, F., \& Hu, K. (2015). Inhibition of hepatitis B virus replication by quercetin in human hepatoma cell lines. Virology Sinica, https://doi.org/10.1007/s12250-015-3584-5.

Davis, J.M., Murphy, E.A., McClellan, J.L., Carmichael M.D., \& Gangemi. J.D. (2008). Quercetin reduces susceptibility to influenza infection following stressful exercise. American Journal of Physiology-Regulatory, Integrative and Comparative Physiology, 295, 505-509. https://doi.org/10.1152/ajpregu.90319.2008.
Değirmenci, U., Nemli, E., \& Çağırgan, H. (2008). Türkiye'nin değişik bölgelerinden infeksiyöz pankreatik nekrozis virusu izolasyonu. I. Ulusal Alabalık Sempozyumu Isparta p. 35.

Dikici, I., Mehmetoglu, I., Dikici, N., Bitirgen, M., \& Kurban, S. (2005). Investigation of oxidative stress and some antioxidants in patients with acute and chronic viral hepatitis $B$ and the effect of interferon- $\alpha$ treatment. Clinical Biochemistry, 38,1141-1144. https://doi.org/10.1016/j.clinbiochem.2005.10.006.

Frankel, E.N., Kanner, J., German, R.S., Parks, E., \& Kinsella, J.E. (1993). Inhibition of oxidation of human low-density lipoprotein by phenolic substances in red wine. Lancet. 341:454-457. https://doi.org/10.1016/0140-6736(93)90206-V.

Frey, H.R., \& Liess, B. (1971). Vermehrungskinetik und Verwendbarkeit eines stark zytopathogenen VD-MDVirusstammes für diagnostische Untersuchungen mit der Mikrotiter-Methode. Zentralblatt für Veterinärmedizin Reihe. B 18, 61-71. https://doi.org/10.1111/j.1439-0450.1971.tb00343.x.

Ganesan, S., Faris, A.N., Comstock, A.T., Wang, Q., Nanua, S., Hershenson, M.B., \& Sajjan, U.S. (2012). Quercetin inhibits rhinovirus replication in vitro and in vivo. Antiviral Research, 94(3), 258-71. https://doi.org/10.1016/j.antiviral.2012.03.005.

Gullberg, R.C., Jordan, J.S., Moon, S., Soltani, E., \& Geiss, J.B. (2015). Oxidative stress influences positive strand RNA virus genome synthesis and capping. Virology, 475, 219 229. https://doi.org/10.1016/j.virol.2014.10.037.

Halliwell, B. (1994). Free radicals and antioxidants: a personal view. Nutrition Reviews, 52,253-265. https://doi.org/10.1111/j.1753-4887.1994.tb01453.x.

Ivanov, A.V., Bartosch, B., \& Smirnova, O.A. (2013). Isaguliants MG, Kocherkov SN. HCV and oxidative stress in the liver. Viruses. 5(2), 439-469. https://doi.org/10.3390/v5020439.

Kang, S.Y., Kang, J.Y., Oh, \& M.J. (2012). Antiviral Activities of Flavonoids Isolated from the Bark of Rhus verniciflua Stokes against Fish Pathogenic Viruses In Vitro. Journal Of Microbiology, 50(2), 293-300. https://doi.org/10.1007/s12275-012-2068-7.

Kelly, G.S. (2011). Quercetin Monograph. Alternative Medicine Review, 16,172-194.

Kujumgiev, A., Tsvetkova, I., Serkedjieva, Y., Bankova, V., Christov, R., \& Popov, S. (1999). Antibacterial, antifungal and antiviral activity of propolis from different geographic origin. Journal Of Ethnopharmacology, 64, 235-240.

https://doi.org/10.1016/S0378-8741(98)00131-7.

Kumar, P., Sharma, S., Khanna, M., \& Raj, H.G. (2003). Effect of Quercetin on lipid peroxidation and changes in lung morphology in experimental influenza virus infection. International Journal of Experimental Pathology, 84, 127-133. https://doi.org/10.1046/j.1365-2613.2003.00344.x.

Lani, R., Hassandarvish, P., Chiam, C.W., Moghaddam, E., Chu, J.J., Rausalu, K., Merits, A., Higgs, S., Vanlandingham, D., Abu Bakar, S., \& Zandi, K. (2015). Antiviral activity of silymarin against chikungunya virus. Scientific Reports, 16, 5-11421. https://doi.org/10.1038/srep11421.

Larson, A.J., Symons, J.D., \& Jalili, T. (2012). Therapeutic potential of quercetin to decrease blood pressure: 
review of efficacy and mechanisms. Advances in Nutrition, 3, 39-46.

https://doi.org/10.3945/an.111.001271.

Lee, M., Son, M., Ryu, E., Shin, Y.S., Kim, J.G., Kang, B.W., Cho, H., \& Kang, H. (2015). Quercetin-induced apoptosis prevents EBV infection. Oncotarget, 6(14), 12603. https://doi.org/10.18632/oncotarget.3687.

Lymbery, A.J. (2000). Genetic Improvement in the Australian Aquaculture Industry. Aquaculture Research, 31, 145149. https://doi.org/10.1046/j.1365-2109.2000.00435.x.

Muller, F. (1992). Reactive oxygen intermediates and human immune deficiency virus (HIV) infection. Free Radical Biology and Medicine, 13, 651-657. https://doi.org/10.1016/0891-5849(92)90039-J.

Nabavi, S.M., Nabavi, S.F., Eslami, S., \& Moghaddam, A.H. (2012). In vivo protective effects of quercetin against sodium fluoride-induced oxidative stress in the hepatic tissue. Food Chemistry, 132(2), 931-935. https://doi.org/10.1039/C2FO10264A.

Najafi, A., Salati, A.P., Yavari, V., \& Asadi, F. (2014). Effects of short-term starvation and re-feeding on antioxidant defense status in Mesopotamichthyssharpeyi (Günther, 1874) fingerlings. International Journal of Aquatic Biology, 2(5), 246-252. http://npajournals.com/ijab/index.php/ijab.

Nishizawa, T., Kinoshita, S., \& Yoshimizu, M. (2005). An approach for genogrouping of Japanese isolates of aquabirnaviruses in a new genogroup, VII, based on the VP2/NS junction region. Journal Of General Virology, 86, 1973-1978. https://doi.org/10.1099/vir.0.80438-0.

Ogut, H., \& Altuntas, C. (2011). Occurrence and prevalence of infectious pancreatic necrosis virus in rainbow trout (Oncorhynchus mykiss) cultured in cages in the Black Sea. Aquacult Res. https://doi.org/10.1111/j.1365-2109.2011.02959.x.

Özcelik, B., Kartal, M., \& Orhan, İ. (2011). Cytotoxicity, antiviral and antimicrobial activities of alkaloids, flavonoids, and phenolic acids. Pharmaceutical Biology, 49(4), 396-402. https://doi.org/10.3109/13880209.2010.519390.

Qiu, X., Kroeker,. A, He, S., Kozak, R., Audet, J., Mbikay, M., \& Chrétien, M. (2016). Prophylactic efficacy of Quercetin3- $\beta$-O-D-glucoside against Ebola virus Infection. Antimicrobial Agents and Chemotherapy, http://dx.doi.org/10.1128/AAC.00307-16.

Rojas, A., et al. (2016). Effect of Quercetin on Hepatitis C Virus Life Cycle: From Viral to Host Targets. Scientific Reports, 6, 31777. https://doi.org/10.1038/srep31777.

Romero, M.R., Efferth, T., Serrano, M.A., Castano, B., Macias, R.I., Briz, O., \& Marin, J.J. (2005). Effect of artemisinin/artesunate as inhibitors of hepatitis B virus production in an "in vitro" replicative system. Antiviral Research, 68, 75-83.

https://doi.org/10.1016/j.antiviral.2005.07.005.

Stehbens, W.E. (2004). Oxidative stress in viral hepatitis and AIDS. Experimental and Molecular Pathology, 77 (2), 121-132. https://doi.org/10.1016/j.yexmp.2004.04.007.

Suzuki, S., \& Nojima, M. (1999). Distribution of a marine birnavirus in wild molluscan shellfish species from Japan. Fish Pathology, 34,121-126. https://doi.org/10.3147/jsfp.34.121.

Wolf, K. (1998). Infectious pancreatic necrosis. In, Wolf K (Ed): Fish viruses and fish viral diseases, Cornell University Press, Ithaca, NY 115-157.

Wu, W., Li, R., Li, X., He, J., Jiang, S., Liu, S., \& Yang, J. (2016). Quercetin as an Antiviral Agent Inhibits Influenza A Virus (IAV) Entry. Viruses, 8,1-6. https://doi.org/10.3390/v8010006.

Yu, M., Si, L., Wang, Y., Wu, Y., Yu, F., Jiao,. P, Shi,Y., Wang, H., Xiao, S., \& Fu, G. (2014). Discovery of pentacyclic triterpenoids as potential entry inhibitors of influenza viruses. Journal of Medicinal Chemistry, 57,1005810071. https://doi.org/10.1021/jm5014067. 